\title{
The Management Scouting Behaviors of Employees in Oil \& Gas Companies in Iraq
}

\author{
Hawra'a Salah Al-Maliki \\ Department of Business Administration \\ Istanbul Aydin University \\ Baghdad, Iraq
}

\author{
Dr. Çiğdem ÖZARI \\ Department of Business Administration \\ Istanbul Aydin University \\ Istanbul, Turkey
}

\begin{abstract}
The main purpose of this study is to outline and identify the influences of employees' job and organizational engagement on their scouting behavior. The study investigates the structural mechanisms between the effectiveness of quality of organizationemployees relationship, intrinsic motivation, creative process engagement, and training effectiveness, as well as their effectiveness on employee scouting. The study was conceived and carried out using the form of Quantitative Analysis. Iraq has identified the survey community; a total of 150 respondents have received from employees of oil and gas companies. Simple and multiple regression analysis was used to analyzing the hypothesis of study. The present study builds on the connectivity parameters of employees at both personal (e.g., intrinsic motivation of creativity, innovative process involvement) and organizational or administrative levels (e.g., the quality of employees' perceived relationship with their organization, perceived training effectiveness) when developing a model that connects the scouting behaviors of employees and their context in a comprehensive measured way. Simple and multiple regression methods were demonstrated between the variables to the examinations of the hypothesis in our study, and by analyzing our data we could support the relationship between the variables and the hypotheses.
\end{abstract}

Keywords:- Employees, Scouting, Creativity, Motivation, Management.

\section{INTRODUCTION}

In any successful organization the tracking "scouting " of the employees' behavior is one of the mainstay to these organizations, and to reach the right bath of behaviors \& relationship of employees with the Management and organization; there is a plenty of circumstances, conditions and needs which both the management and employees should follow-up. Considered as one of the strategic constituencies to any organization, the behavior of employee; could be key factors in reaching a novelty inside any organization. This research will be analyzing the employees' performance, creativity, development and for sure behaviors; which the Managements side of each organization should be aware of them. And the reasons affecting this method (the scouting behavior of employees) and what is the steps or actions that management need to apply for achieving the positive results they are looking for.
Successful organizations know how to motivate employees to achieve the target the are planned to follow and to know how to build a backup relationship with them. And this is an important reason for these organizations to have a system for employees to put them into managerial process so they can participate that they can be able to help in defining emerging problems or opportunities, practices or creative thoughts which lead to innovation. Organization must be aware of employees that they are one of the most strategic publics, which they can contribute in the innovation process of the organization and they can make it more entrepreneurial by the information they deliver through their behaviors in the tasks and work routines.

The purpose of this study is to encourage organizations to let more employees to engage in active information acquiring and let more employees to share behaviors which lead to more opportunities to achieve innovation by the information provided by employees. The engagement of employees in communicative action is an important factor to encourage them, which is in addition to individual's capacity to be creative in their work. Management should be aware that building a good relationship with employees has been emphasized as a key factor of organization effectiveness (Lee, 2018, pp. 286-294)

\section{LITERATURE REVIEW}

\section{A. Strategic importance of employees' communicative} behaviors (ECBS):

In the organizational performance, employees' behaviors are in the first flight to be recognized, all through the disciplines which include business, human resources, and communication management have attempted to put these behaviors in conceptualization from different perspectives. For example, (Linn Van Dyne, 2003, pp. 1359-1392)and (Morrison, 2014, pp. 173-197) conceptualized employee sound and silence behaviors as possession of multiple dimensions, recognizing employees' different motivations to prohibit or explicit ideas, information, and point of views about improvements in work. Two fundamental factors have been stated by academic estimation: job satisfaction and job alternatives, employees who are satisfied in their jobs ( for example, they are pleased with their salaries, expecting a promotion, happy with the environment of the work and the tasks they are assigned to do) will maintain in their jobs, otherwise they will tend to leave. In the measuring the similar level of dissatisfaction, employees dealing with more 
alternatives will tend to leave vice versa with those of a little alternative (Terence R. Mitchell, 2011, pp. 96-108).

\section{B. Maintaining the Integrity of the Specifications}

The template is used to format your paper and style the text. All margins, column widths, line spaces, and text fonts are prescribed; please do not alter them. You may note peculiarities. For example, the head margin in this template measures proportionately more than is customary. This measurement and others are deliberate, using specifications that anticipate your paper as one part of the entire proceedings, and not as an independent document. Please do not revise any of the current designations.

\section{Motivations for scouting: organizational efforts}

Motivation was stemmed from the Latin word mover, indicating to move (Sunil Ramlall, 2004, pp. 52-63) Motivation depicts "those psychological mechanism which causes the enthusiasm, direction, and assertiveness of goaloriented cooperative behavior. (Robbins, 2016, p. 247) defined motivation as the mechanisms which compensate for the strength, direction and persistence of an individual's efforts to achieve an objective. Though general motivation requires efforts against some goal. The motivation of person to carry out an activity relies on the anticipated fulfilling consequences - or benefits - of participating in that activity, and perhaps even the strength of their desires for these advantages. Employees are often more likely to cooperate and share ideas while they were involved of a working community with guidelines for communicating thoughts, opinions and strongest practices to encourage innovation, expression and information exchange among employees (Morrison, Elizabeth W., 2011, pp. 373-412).

\section{Employees creative process}

Lately, companies are becoming much more encouraged to promote innovation among their employees (Christian.E. Shalley, 2004, pp. 33-53) because suggestions from workers to supervisors to develop operations, goods and services could really offer competitiveness significant benefits (Isabel C. Botero, 2009, pp. 84-104). And to talk about creativity and creative process we've collected the following information: Creativity: Creative people as well as the mechanisms via which they demonstrate their creativity have disturbed a great deal of concern and curiosity. (John R. Hayes, Carnegie Mellon, 1989, p. 18). Creative "is a word with several meanings. It is often used to characterize people's ability to create creative works if they may have completed any work or not yet (John R. Hayes , Carnegie Mellon, 1989, p. 18). despite the usual application of the word creativity to people, instances of creative processes appear into the natural world. The physical mechanisms of cosmological and biological progression that compose the substratum of our existence illustrate spontaneous innovation, as have the broader sociological and economic systems through which humanity function. The very important characteristic of psychodynamic systems is imagination too (John R. Hayes, Carnegie Mellon, 1989, p. 18). Given the vagaries of these judgments, there seems to be a core of three assessments which encompass the determination of a creative act:
- The behavior should be seen as unique or novel;

- It would rather be considered beneficial or intriguing

- It should exemplify well on the creator's opinion.

\section{E. Creative process engagement}

For order to engage in a creative process people should be sufficiently inspired to be innovative. This his research also regarded creativity's intrinsic motivation more as an antecedent of individual factors, referring to the degree to which an individual is self-originated, involved in a task, and engaged in it towards the benefit of the assignments themselves. It is taken into consideration a proven indicator of creativity at workplace as just an independent factor (Christian.E. Shalley, 2004, pp. 33-53). The more connections a person has to the necessary aspects of a problem, the larger the possibility that he should find a creative approach. (Xiaomeng zhang, 2010, pp. 107-128) Stated, that the extent towards involvement in creative activity fluctuates, if a person pays scant interest to a problem and opts to limitedly participate during its resolution, solutions that not be innovative and productive.

\section{F. Training effectiveness'}

Training is essential for increasing the incidence of innovative thinking techniques, so it could generate educational advantages which could instill experience in the assignment realm. Training involves providing new or existing employees the expertise maybe they just need to carry out respective duties (DESSLER, 2013, p. 246). Training programs toward advancement, job bidding (particularly in unionized jobs), or wage raises can be needed. In general, equivalent opportunities for training should indeed operate among all employees (David A. DeCenzo, 2013, p. 200). Employee training is an educational perspective: To enhance work presentation, it requires a fairly positive shift among workers. Training therefore requires educating modern qualifications, awareness, perceptions, and/or attitude (David A. DeCenzo, 2013, p. 202). That can indicate updating what employees believe, how they perform, or attitudes regarding certain jobs, colleagues, administrators, as well as the organization.

\section{G. Scouting behaviors}

Scouting is the "voluntary contact actions by workers to deliver important knowledge to the organization" (Rhee, 2011, pp. 243-268). As said by (Dozier, 1986, pp. 1-29), environmental screening could be described as" the collection of public information, community responses to the organization, and community viewpoint on organizationsignificant issues" (Rhee, 2011, pp. 243-268). The conceptual foundation for scouting could be observed in literature along the environmental filtering. A certain research suggests scouting as the voluntary knowledge activities of the specific employee, not just participating and finding information collected throughout the formal and informal encounters of the employee with strategic organizational stakeholders, yet, exchanging and transmitting this information to the company by the employee. Unlike the current literature on environmental mapping, scouting focuses on the cumulative amount of the cooperation endeavors of non-public relations professional employees. 
farther more, relying upon a study of related literature, megaphoning and scouting principles are combined in order to conceptualize micro-frontier ranging (Rhee, 2011, pp. 243268).

\section{H. Motivations for scouting: Individual characteristics}

Intrinsic motivation is special to the participant and therefore can differentiate according to the role within the employee (Ryan \& Deci, 2000). Intrinsic motivation is characterized as the inherent mortal urge through exercise or competition to implement and improve one's qualifications or capacities (Ryan \& Deci, 2001). Organizations are comprised of individuals who strive with one another to meet targets. (David A. DeCenzo, 2013, p. 211). employee involvement and Participation (EIP) is a mechanism that incorporates feedback from workers to strengthen their contribution to organizational performance. When employees are participated in decision making which enhance their flexibility and influence over their working habits, they would appear highly empowered, further organizationdriven, highly efficient, and even happier about their jobs.

\section{1) Organizational Commitment :}

An organizationally dedicated employee recognizes with a single institution and its objectives and wants to maintain a participant. An organization's psychological dedication as well as trust in its principles is the "gold benchmark" for employee engagement. Employees who have been dedicated are fewer inclined to participate in job withdrawal even though they are unhappy since they maintain an impression of commitment or connection to the organization. And if workers have not been presently satisfied with their jobs, if they have been dedicated sufficiently, they are able to offer sacrifices to the organization (Stephen P. Robbins, 2016, p. 116).

\section{2) Employee Engagement :}

Employee participation is the participation, satisfaction with, and excitement of a person for the work he or she is performing. We may ask employees to measure engagement whether they have accessibility to resources and opportunities to acquire modern techniques, if they believe their job is fundamental and worthwhile, and whether communications with teammates and managers are satisfying. greatly involved employees have an enthusiasm for their jobs and have a strong bond with their businesses; disengaged workers have basically dropped out, bringing effort towards their jobs but not power or attention. Engagement is a major problem among most companies as researches demonstrate that little employees - between $17 \%$ and 29\% - are strongly dedicated to their jobs (Robbins, 2016, p. 117).

\section{CONCEPTUAL FRAMEWORK OF HYPOTHESIS}

In this study we have stated the problem and it's subproblems, and by this work we have stated the hypothesis of the research, in which the main variable is the scouting behaviors of employees and it is relationship with the other variables which are mainly affect the main variable which is (scouting behavior) in specific hypothesis connections and these variables are: quality of organization-employee relationships, intrinsic motivation, creative process, and training, through how they positively or negatively affect the main element of the research which is the dependent variable (scouting behavior), which led the work to the conceptual model of the research:

The study will be based on the following hypotheses: HA: The quality of employees' perceived relationship with their organization is positively related to their scouting behavior.

$\mathrm{HB}$ : Individuals' intrinsic motivation for creativity is positively related to the quality of employees' perceived relationship with their organization

$\mathrm{HC}$ : Individuals' intrinsic motivation for creativity is positively related to their creative process engagement.

HD: Employees' creative process engagement is positively related to employees' scouting behavior.

HE: Employees' perceived training effectiveness is positively related to their motivation.

$\mathrm{HF}$ : Individuals' intrinsic motivation for creativity is positively related to their scouting behavior.

Fig. 1. Conceptual model

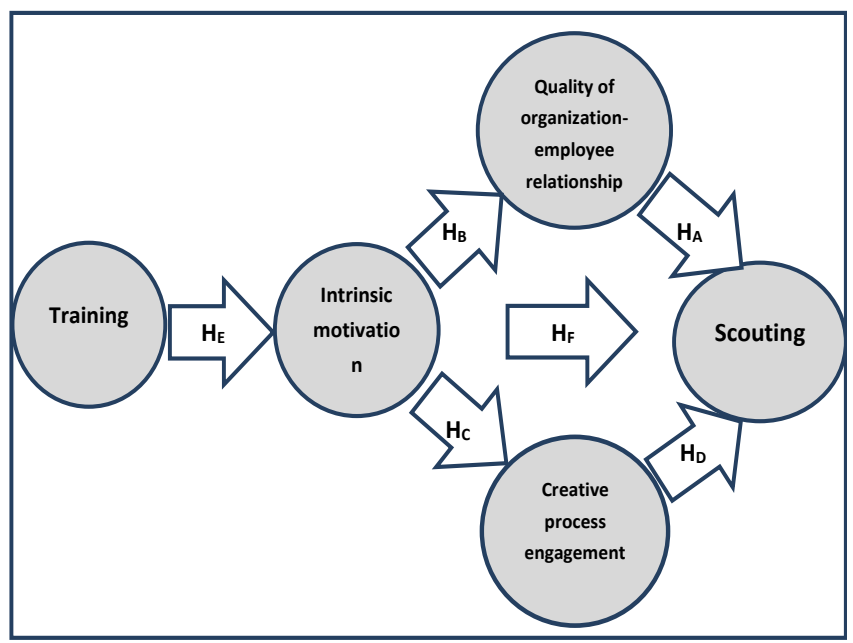

Source: made by the author 


\section{METHODOLOGY:}

In this study we have used the Convenience / Purposive Sampling Method a type on non-probability sampling: which is regarded as the most widely applied sampling method. The online questionnaire was created by Google forms then distributed among employees of oil and gas companies in Iraq. And this is why they are recruited though at the appropriate moment; they are in the correct location. It is clearly understood that the work of this study has been structured quantitatively. The study's sample consisted of 150 participants which is all were employees at oil and Gas companies in Iraq. Percentage of females were about 28,7\% in number of 43 female, and percentages of male were about $71.3 \%$ in number of 107 males. 8 peoples were between the age of 18-24 (5.3\%), 107 peoples were between the age of $25-34$ (71.3\%), 24 peoples were between the age of 35-44 (16\%), and 11 peoples were between the age of 45 and above (7.3\%). Participants were recruited via an online research management system. The online system provides information on a variety of employees that individuals may elect to participate in for credit that is required by their university curriculum.

\section{ANALYSIS AND DISCUSSION}

\section{A. Demographic Profile of Respondents}

The demographic profile of this study consists of five questions, each of which represents an important point of understanding the characteristics of the individuals who responded to the survey.

Table 1: Demographic respondents

\begin{tabular}{|c|c|c|c|c|}
\hline Demographics Profile & Variables & Frequency & Percent & $\begin{array}{c}\text { Cumulative } \\
\text { Percent }\end{array}$ \\
\hline \multirow[t]{2}{*}{ Gender } & Male & 106 & 71.1 & 71.1 \\
\hline & Female & 43 & 28.9 & 100.0 \\
\hline \multirow[t]{4}{*}{ Age } & $18-24$ & 8 & 5.4 & 5.4 \\
\hline & $25-34$ & 107 & 71.8 & 77.2 \\
\hline & $35-44$ & 23 & 15.4 & 92.6 \\
\hline & 45 or more & 11 & 7.4 & 100.0 \\
\hline \multirow[t]{3}{*}{ Education } & High school or less & 2 & 1.3 & 1.3 \\
\hline & Undergraduate (Bachelor) & 110 & 73.8 & 75.2 \\
\hline & Graduate (Master, PHD) & 37 & 24.8 & 100.0 \\
\hline \multirow[t]{5}{*}{ work years } & $0-5$ & 83 & 55.7 & 55.7 \\
\hline & $5-10$ & 50 & 33.6 & 89.3 \\
\hline & $10-15$ & 9 & 6.0 & 95.3 \\
\hline & $15-20$ & 4 & 2.7 & 98.0 \\
\hline & morethan 20 & 3 & 2.0 & 55.7 \\
\hline \multirow[t]{6}{*}{ Number of trainings } & none & 21 & 14.1 & 14.1 \\
\hline & $1-5$ & 73 & 49.0 & 63.1 \\
\hline & $5-10$ & 29 & 19.5 & 82.6 \\
\hline & $10-15$ & 15 & 10.1 & 92.6 \\
\hline & $15-20$ & 5 & 3.4 & 96.0 \\
\hline & morethan 20 & 6 & 4.0 & 100.0 \\
\hline
\end{tabular}

Source: Made by author

\section{B. Reliability of Measurements}

Reliability of Measurements Reliability can be measured using the alpha test of the Cronbach, it gives a measure of a scale 's internal accuracy (Ghaleb \& Kaplan, 2020 , p. 134). Reliability coefficient defines the degree to which the same definition or model is evaluated by all the elements in a test (Tavakol \& Dennick, 2011). "The alpha coefficient of Cronbach is between 0 and 1 , the higher the score, the more accurate the scale. 0.7 or more is an adequate reliability result" (Santos \& Reynaldo, 1999). According to the table below the coefficient Cronbach's Alpha were above the appropriate value of 0.7 for the measurements in this analysis, which prove that our scales were reliable and can be used to analyze the hypothesis.

Table 2: Reliability Assessment (Alpha test):

\begin{tabular}{cccc}
\hline Variable name & Cronbach's Alpha & $\begin{array}{c}\text { Cronbach's Alpha Based } \\
\text { on Standardized Items }\end{array}$ & $\begin{array}{c}\text { N of } \\
\text { Items }\end{array}$ \\
\hline Scouting & .830 & .833 & 4 \\
$\begin{array}{c}\text { Quality of organization- } \\
\text { employee relationship } \\
\begin{array}{c}\text { Creative process } \\
\text { engagement \& } \\
\text { Symmetrical } \\
\text { communication efforts }\end{array}\end{array}$ & .937 & .937 & 10 \\
$\begin{array}{c}\text { Training effects } \\
\text { Intrinsic motivation of } \\
\text { creativity }\end{array}$ & .929 & .929 & 13 \\
\hline Source: Made by author & .923 & .850 & 3 \\
\hline
\end{tabular}

\section{Normality Assessment}

Normality Degree at whom the provided data distribution matches a normal distribution. Normality in multivariate analyzation the most foundational assumption is normality, responding to the shape of the data distribution for a specific metric variable and its correspondence with the normal distribution, the benchmark for statistical methods (Hair Jr. , Black, Babin , \& Anderson , 2014, p. 69). According to (Hair Jr. , Black, Babin , \& Anderson, 2014, p. 33) the definition of Skewness: evaluate the symmetry of a distribution; a difference is made to a normal distribution for most cases. A positively skewed variation has considerably few large values and slats to the right, and a negative skewed variation has remarkably fewer small values and slats to the left. Skewness values that fall beyond the -1 to +1 range suggest a considerably skewed spectrum. And Kurtosis: Measurement of a distribution's peakness or flatness as regards to normal distribution. A positive value shows a comparatively strong distribution, and a negative value shows a relatively flat distribution. By looking to our Table 5 which shows negative skewed for variable 1,2,3,4,5 and this means we have shifted to left data distribution. While Kurtosis values fluctuate between positive and negative and that means that the peakness of our data is also between strong and flat distribution. 
Table 3: Skew and Kurtosis results:

\begin{tabular}{|c|c|c|c|c|c|}
\hline & Skew & Kurtosis & & Skew & Kurtosis \\
\hline Variable 1. & & & Con. variable 3 . & & \\
\hline Scouting 1: & -0.782 & 0.129 & $\begin{array}{l}\text { Creative process } \\
\text { engagement } 4 \text { : }\end{array}$ & -1.094 & 0.736 \\
\hline Scouting 2: & -0.693 & -0.412 & $\begin{array}{l}\text { Creative process } \\
\text { engagement 5: }\end{array}$ & -1.126 & 0.533 \\
\hline Scouting 3: & -0.742 & -0.084 & $\begin{array}{l}\text { Creative process } \\
\text { engagement } 6 \text { : }\end{array}$ & -1.163 & 1.096 \\
\hline Scouting 4: & -0.859 & -0.164 & $\begin{array}{l}\text { Creative process } \\
\text { engagement } 7 \text { : }\end{array}$ & -0.981 & 0.663 \\
\hline Variable 2. & & & $\begin{array}{l}\text { Creative process } \\
\text { engagement } 8 \text { : }\end{array}$ & -1.066 & 0.622 \\
\hline Trust 1: & -0.207 & -0.793 & $\begin{array}{l}\text { Creative process } \\
\text { engagement 9: }\end{array}$ & -1.059 & 0.893 \\
\hline Trust 2: & -0.483 & -0.633 & $\begin{array}{l}\text { Symmetrical comm- } \\
\text {-unication effort } 1\end{array}$ & -0.652 & -0.286 \\
\hline Trust 3: & -0.476 & -0.607 & $\begin{array}{l}\text { Symmetrical comm- } \\
\text {-unication effort } 2\end{array}$ & -0.461 & -0.397 \\
\hline Trust 4: & -0.563 & -0.623 & $\begin{array}{l}\text { Symmetrical comm- } \\
\text {-unication effort } 3\end{array}$ & -0.524 & -0.464 \\
\hline Commitment 1: & -0.438 & -0.727 & $\begin{array}{l}\text { Symmetrical comm- } \\
\text {-unication effort } 4\end{array}$ & -0.673 & 0.038 \\
\hline Commitment 2: & -0.553 & -0.445 & Variable 4. & & \\
\hline Commitment 3: & -0.644 & -0.438 & Training 1: & -1.540 & 2.139 \\
\hline Satisfaction 1: & -0.654 & -0.353 & Training 2: & -0.859 & 0.453 \\
\hline Satisfaction 2: & -0.804 & 0.010 & Training 3: & -1.264 & 0.911 \\
\hline Satisfaction 3: & -0.886 & 0.177 & Variable 5. & & \\
\hline Variable 3. & & & $\begin{array}{l}\text { Intrinsic motivation } \\
\text { of creativity 1: }\end{array}$ & -1.026 & 0.610 \\
\hline $\begin{array}{l}\text { Creative process } \\
\text { engagement 1: }\end{array}$ & -0.910 & 0.048 & $\begin{array}{l}\text { Intrinsic motivation } \\
\text { of creativity } 2 \text { : }\end{array}$ & -1.291 & 1.478 \\
\hline $\begin{array}{l}\text { Creative process } \\
\text { engagement } 2 \text { : }\end{array}$ & 0.194 & 0.194 & $\begin{array}{l}\text { Intrinsic motivation } \\
\text { of creativity } 3 \text { : }\end{array}$ & -1.038 & 0.606 \\
\hline $\begin{array}{l}\text { Creative process } \\
\text { engagement } 3 \text { : }\end{array}$ & -0.858 & 0.083 & & & \\
\hline
\end{tabular}

Source: Made by author

\section{Multi-Collinearity analysis}

Collinearity Description of the relation between two independent variables (collinearity) or more (multicollinearity). When their correlation coefficient is 1 , two independent variables are assumed to show complete collinearity, and total absence of collinearity when their correlation coefficient is 0 . Multicollinearity happens when there is strong overlap between some single independent variable and a number of other independent variables. The Variance Inflation Factor (VIF) and tolerance are further commonly adopted measurements of the degree of multicollinearity of the independent variable in a statistical model with the other independent variables in it (O'BRIEN, 2007, p. 674). As finale talk the VIF must be less than 3 and tolerance must be above 0.1 to conclude there is no
Multicollinearity issue in our samples (O'BRIEN, 2007, p. 673). And according to the table (6) the data of our variables shows no multicollinearity in all the cases, except Part 3 where the VIF in Variable equal (3.034) which it could be ignored because it is means there is a very small chance to have Multicollinearity issue because depending on the Tolerance which equal (0.330) there is no Multicollinearity issue.

Table 4: Multi-Collinearity analysis results:

\begin{tabular}{|c|c|c|}
\hline Collinearity Statistics: Part 1 & & \\
\hline Dependent Variable: Variable 2 & Tolerance & VIF \\
\hline Variable 3 & 0.370 & 2.703 \\
\hline Variable 4 & 0.427 & 2.339 \\
\hline Variable 5 & 0.367 & 2.722 \\
\hline \multicolumn{3}{|l|}{ Collinearity Statistics: Part 2} \\
\hline Dependent Variable: Variable 3 & Tolerance & VIF \\
\hline Variable 2 & 0.656 & 1.524 \\
\hline Variable 4 & 0.480 & 2.082 \\
\hline Variable 5 & 0.437 & 2.290 \\
\hline \multicolumn{3}{|l|}{ Collinearity Statistics: Part 3} \\
\hline Dependent Variable: Variable 4 & Tolerance & VIF \\
\hline Variable 2 & 0.520 & 1.922 \\
\hline Variable 3 & 0.330 & 3.034 \\
\hline Variable 5 & 0.425 & 2.355 \\
\hline \multicolumn{3}{|l|}{ Collinearity Statistics: Part 4} \\
\hline Dependent Variable: Variable 5 & Tolerance & VIF \\
\hline Variable 2 & 0.525 & 1.905 \\
\hline Variable 3 & 0.352 & 2.843 \\
\hline Variable 4 & 0.499 & 2.006 \\
\hline
\end{tabular}

Source: Made by author

E. Regression Analysis for Hypotheses Testing:

1) Simple Regression analysis:

Linear Regression means a relationship of straight line (Hanke \& Wichern, 2014, p. 175), After forming a linear equation, knowledge of the independent variable will be used to evaluate the dependent variable. A sample of the $\mathrm{X}-$ $\mathrm{Y}$ values produces the equipped regression line.

- According to (Hair Jr. , Black, Babin , \& Anderson , 2014, p. 159)With the coefficient of interception and regression estimated by the least square's procedure, attention is now turned to interpretation of these two values:

- The Coefficient of Regression: The expected adjustment in the dependent variable for the independent variable to adjustment function. When the coefficient of regression is considered to be statistically important (i.e. the coefficient is substantially different from zero), the significance of the coefficient of regression shows to the degree the independent variable is correlated with the dependent variable. 
- The intercept has interpretative definition only if zero is a conceptually true value for an independent variable (i.e. the independent variable will have a value of zero and yet preserve its functional significance).

- =If the independent valuation is a variable which will never include a true value of zero, the intercept aims to strengthen the mechanism of estimation, and who has no interpretative result at all.

Table 5: The Simple Regression Analysis for Hypotheses Testing results:

\begin{tabular}{|c|c|c|c|c|c|c|c|}
\hline \multirow[b]{2}{*}{ Hypothesis } & \multirow[b]{2}{*}{$\begin{array}{c}\text { Dependent } \\
\text { Variable } \\
\end{array}$} & \multirow{2}{*}{$\begin{array}{c}\text { Independent } \\
\text { Variable }\end{array}$} & \multicolumn{2}{|c|}{$\begin{array}{l}\text { Unstandardized } \\
\text { Coefficients }\end{array}$} & \multirow{2}{*}{$\begin{array}{c}\begin{array}{c}\text { Standardize } \\
\mathrm{d} \\
\text { Coefficients }\end{array} \\
\text { Beta }\end{array}$} & \multirow[b]{2}{*}{$\mathrm{t}$} & \multirow[b]{2}{*}{ Sig. } \\
\hline & & & B & Std. Error & & & \\
\hline $\mathrm{H}_{\mathrm{A}}$ & Variable 1 & Variable 2 & 0.280 & 0.024 & 0.696 & 11.756 & 0.000 \\
\hline $\mathrm{H}_{\mathrm{B}}$ & Variable 2 & Variable 5 & 1.750 & 0.209 & 0.568 & 8.372 & 0.000 \\
\hline $\mathrm{H}_{\mathrm{C}}$ & Variable 3 & Variable 5 & 2.628 & 0.188 & 0.756 & 13.987 & 0.000 \\
\hline $\mathrm{H}_{\mathrm{D}}$ & Variable 1 & Variable 3 & 0.248 & 0.021 & 0.697 & 11.779 & 0.000 \\
\hline $\mathrm{H}_{\mathrm{E}}$ & Variable 5 & Variable 4 & 0.750 & 0.061 & 0.710 & 12.231 & 0.000 \\
\hline $\mathrm{HF}$ & Variable 1 & Variable 5 & 0.806 & 0.078 & 0.650 & 10.370 & 0.000 \\
\hline
\end{tabular}

Source: Made by author

\section{2) Multiple Regression Analysis:}

Multiple regression analysis is a statistical method where can be applied to analyze the connection among a single dependent variable (criterion) and numerous independent variables (predictor) as described by (Hair Jr. , Black, Babin , \& Anderson , 2014, p. 157), which also stated that Multiple regression analyzes tend to be using the independent variables for whom the values are recognized to estimate the researcher's chosen single dependent value. The proportions symbolize the relative ability to contribute of the independent variables to the overall forecast, which promote understanding of the effect of each variable in building the forecast, while interaction between the independent variables complicates the interpretative process. For the regression model the most widely used indicator of predictive precision is the decision coefficient (R2). Estimated as the squared correlation among the dependent variable 's genuine and expected values, it describes the cumulative results of the whole variate (one or multiple independent variables or intercept) in forecasting the dependent variable. It varies between 1.0 (perfect prediction) and 0.0 (no prediction). Although the incorporation of independent variables will still induce the determination coefficient to increase, the modified determination coefficient may decline if the additional independent variables have no interpretative capacity or if the degrees of freedom are too small. And from the table 7 we interpret our Model's relationships as positive relationships.
Table 6: Multiple regression Analysis:

\begin{tabular}{|c|c|c|c|c|}
\hline Model & $\mathrm{R}$ & R Square & Adjusted R Square & $\begin{array}{l}\text { Std. Error of the } \\
\text { Estimate }\end{array}$ \\
\hline 1 & 0.762 & 0.580 & 0.574 & 2.40929 \\
\hline \multicolumn{5}{|c|}{ Predictors: (Constant), VARIABLE2, VARIABLE5 } \\
\hline \multicolumn{5}{|c|}{ Dependent Variable: VARIABLE1 } \\
\hline Model & $\mathrm{R}$ & R Square & Adjusted R Square & $\begin{array}{l}\text { Std. Error of the } \\
\text { Estimate }\end{array}$ \\
\hline 2 & 0.666 & 0.443 & 0.436 & 2.77467 \\
\hline \multicolumn{5}{|c|}{ Predictors: (Constant), VARIABLE5, VARIABLE4 } \\
\hline \multicolumn{5}{|c|}{ Dependent Variable: VARIABLE1 } \\
\hline Model & $\mathrm{R}$ & R Square & Adjusted R Square & $\begin{array}{l}\text { Std. Error of the } \\
\text { Estimate }\end{array}$ \\
\hline 3 & .722 & 0.521 & 0.514 & 2.57335 \\
\hline
\end{tabular}

Predictors: (Constant), VARIABLE3, VARIABLE5

Dependent Variable: VARIABLE1

Source: Made by author

\section{FINDINGS AND CONCLUSIONS}

The objective of this study was to examine the scouting behaviors of employees by management, and what is the distinct influence of management on employees what is the accurate practice management could apply to reach the organization's targets. This study made many contributions to strategic official management and business development, both technically and actually, in investigating the motivating routes for employees to participate in searching, as well as their voluntary knowledge gathering and transmitting actions. The results are all standardized. The scale, standard deviations, and correlations between the variables are listed in Tables. The coefficient alphas were above the appropriate value of 0.7 for the measurements in this analysis.

Part of this research findings confirmed by (Lee, 2018) In exploring the motivational destinations for employees to engage in scouting, as well as their individual behavior of acquiring and transmitting information.

There is a number of findings we could conclude from the Hypotheses in this research:

First finding of this research is that: The quality of employees' perceived relationship with their organization is positively related to their scouting behavior. Test findings for the first scouting behavior model showed that the maintenance of successful relationships with its employees could contribute to productive advantages for organizations. Parallel with previous findings, we observed a major impact of the consistency of the relationship between organization and employee on scouting, suggesting that a relationshipbuilding approach is essential for organizations to promote the successful communication activity of employees. 
The final conclusion is: In HA, we expected a positive relationship between organization-employee relationship and scouting behavior. A positive relationship $(B=0.280$, Std. Error $=0.024$, beta $=0.696$ ) was found, and thus H1 was supported.

Second finding of this research is that: Individuals' intrinsic motivation for creativity is positively related to the quality of employees' perceived relationship with their organization, Since employees trust and are satisfied with their organization, and believe they can manage the organization collectively and commit to each other, they are likely to pass on and exchange important knowledge relevant to the company.

The final conclusion is: In $\mathrm{HB}$, we expected a positive relationship between intrinsic motivation for creativity and quality of employees' perceived relationship with their organization. A positive relationship $(B=1.750$, Std. Error $=0.209$, beta $=0.568$ ) was found, and thus HB was supported.

Third finding of the research is that: Employees' creative process engagement is positively related to employees' scouting behavior. In addition, we assumed that because scouting behavior is marked by cooperative efforts on the part of employees, their communicative motives should not be disregarded at individual level. The current study empirically demonstrated that engagement of individuals whom were intrinsically motivated toward being creative in the behavioral process of innovative problemsolving influences an essential role in directing individuals to create, and choose, and bring precious information from the outside through a company that is critical to the innovation of an organization.

A significant relationship between Employees' creative process engagement and scouting behavior, $(B=0.248$, Std. Error $=0.021$, beta=0.697) supported Hypothesis HD, Employees' creative process engagement positively predicted the overall scouting behavior of their management.

Fourth finding of the research is that: Individuals' intrinsic motivation for creativity is positively related to their creative process engagement. We also examined two additional alternative concepts that concentrated on relationships between intrinsic motivation, participation in creative processes, and innovation among employees. To give an introductory view at what could affect employee involvement in a successful creative process by reflecting on the stage in the process of creating the concept. In addition, we exemplify the significant mediation effect of creative process engagement for creativity in terms of both organizational commitment and intrinsic motivation.

The final conclusion is: In HC, we expected a positive relationship between Individuals' intrinsic motivation for creativity and their creative process engagement. A positive relationship $(B=2.628$, Std. Error $=0.188$, beta=0.756) was found, and thus HC was supported.
Fifth finding of the research is that: Employees' perceived training effectiveness is positively related to their motivation. (Sirota \& Klein, 2014) Assert that motivation is directly linked to the need for achievement originating from training and learning which is achieved by job development. Supplying opportunities through successful action and encouraging employees to fulfill innovative strategies, take reasonable chances and test creative approaches impact workplace performance through expanding employee motivation, a sensation of belonging for employees as well as a depth of individual and organizational understanding for employees. Eventually, the feeling of being sponsored for training is often strongly linked to corporate loyalty.

The final conclusion is: In HE, we expected a positive relationship between Employees' perceived training effectiveness and their motivation. A positive relationship $(\mathrm{B}=0.750$, Std. Error $=0.061$, beta=0.710) was found, and thus HE was supported.

Sixth finding of the research is that: Individuals intrinsic motivation for creativity is positively related to their scouting behavior. Finally, two distinctive employee scouting behaviors and intrinsic creative motivation were established. This study made many contributions to strategic internal cooperation and management development, both logically and functionally, in investigating the motivating avenues for employees to participate in scouting, as well as their cooperative information gathering and sharing of information behavior. In accordance with prior results, we found a significant effect of the reliability of the correlation between organization and employee on scouting, demonstrating how a relationship-building strategy is extremely important for organizations to accommodate the efficient information behavior of employees. In this respect, this study conceptually demonstrated that participation of individuals whom were inherently driven to be innovative in the behavioral phase of imaginative problem-solving characters a major role in guiding them to develop, identify, and deliver worthwhile information from outside through an organization which is essential for the creativity of an company.

The final conclusion is: In HF, we expected a positive relationship between Individuals' intrinsic motivation for creativity and their scouting behavior. A positive relationship $(B=0.806$, Std. Error $=0.078$, beta $=0.650)$ was found, and thus HF was supported.

\section{LIMITATIONS AND RECOMMENDATIONS}

Every research should have several limitations. Firstly, the sample size used in this analysis was only 150 employees in oil and gas companies in Iraq that means unable to generalize the results for all Employees in different sectors and organizations. Secondly, there might be other variables could contribute in the study but according to the time limit we could not be all included. Finally, because of the covid19 the author faced time and area complications in the last part of the study era. 
For further researches in the management scouting behaviors, this study could be applied in another sectors than oil and gas companies, also it might be applied in different countries for the same sector.

\section{REFERENCES}

[1]. Anita S Acharya, A. P. ( 2013). Sampling: Why and How of it? INDIAN JOURNAL OF MEDICAL SPECIALITIES, 330-333.

[2]. Blanchard, C. M. (2008). Iraq: Oil and Gas Legislation,. Analyst in Middle Eastern Affairs : Foreign Affairs, Defense, and Trade Division.

[3]. Blanchard, C. M. (2008). Iraq: Oil and Gas Legislation, Revenue Sharing, and U.S. Policy. in Middle Eastern Affairs : crs report for congress .

[4]. Bryman , A., \& Bell, E. (2011). Business Research Methods. New York: Oxford University Press Inc., New York.

[5]. Christian.E. Shalley, L. G. (2004). What leaders need to know: A review of social and contextual factors that can foster or hinder creativity. The Leadership Quarterly 15, 33-53.

[6]. D.Bruning, J. A. (1998). Relationship management in public relations: dimensions of an organization-public relationship. Public Relations Review, 55-65.

[7]. David A. DeCenzo, S. P. (2013). Fundamentals of Human Resource Management . United States of America : John Wiley \& Sons, Inc.

[8]. DESSLER, G. ( 2013). HUMAN RESOURCE MANAGEMENT. United States of America: Pearson Education,Inc.,publishing as Prentice Hall.

[9]. Dozier, D. M. (1986). The environmental scanning function of public relations practitioners and participation in management decision making. Association for Education in Journalism and Mass Communication, Norman, OK. , 1-29.

[10]. Farrar , D. E., \& Glauber , R. R. ( 1967). MULTICOLLINEARITY IN REGRESSION ANALYSIS: THE PROBLEM REVISITED. The MIT Press , 92-107.

[11]. Ghaleb, M., \& Kaplan, B. (2020). Branding and Yemeni Organizations' Willingness to Pay a Price Premium for Audit Services. ISTANBUL MANAGEMENT JOURNAL, 127-143.

[12]. Grunig, L. C. (1999). Guidelines for Measuring Relationships in Public Relations. Florida, USA: Institute for Public Relations.

[13]. Hair Jr. , J., Black, W., Babin , B., \& Anderson , R. (2014). Multivariate Data Analysis (Person's new international edition) (Seventh Edition ed.). London: British Library Cataloguing-in-Publication Data.

[14]. Hanke, J. E., \& Wichern , D. (2014). Business Forecasting, Person new international edition. London: Pearson.

[15]. Henry Sauermann, W. M. (2010). What Makes Them Tick? Employee Motives and Firm Innovation. INFORMS, 2134-2153.

[16]. HuaJiang. (2012). A model of work-life conflict and quality of employee-organization relationships (EORs): Transformational leadership, procedural justice, and family-supportive workplace initiatives. public relation review, 231-245.

[17]. Isabel C. Botero, L. V. (2009). Employee Voice Behavior Interactive Effects of LMX and Power Distance in the United States and Colombia. Management Communication Quarterly, 84-104.

[18]. jeong-namkim, 1.-1. (2008). Breaking down the stakeholdere

nvironment:explicatingapproachestothesegmentationof publicsforpublicrelationsresearch. Journalism \& mass communication quarterly, 751-768.

[19]. John R. Hayes , Carnegie Mellon. (1989). Handbook of Creativity. New York, New York, USA: plenum press. Retrieved January, 1990

[20]. Lee, M. K.-N. (2018). Looking for motivational routes for employee-generated innovation: Employees' scouting behavior. Journal of Business Research, 286294.

[21]. Leedy , P. D., \& Ormrod , J. E. (2010). Practical Research PLANNING AND DESIGN. In K. M. Davis. Upper Saddle River, New Jersey 07458: Published by Merrill.

[22]. Lewis-Beck, M. (1995). Data analysis an introdution. London : Sage pablication.

[23]. Linn Van Dyne, S. A. (2003). Conceptualizing Employee Silence and Employee Voice as Multidimensional Constructs*. Journal of Management Studies , 1359-1392.

[24]. MATHIEU, J. E., \& MARTINEAU , J. W. (1993). INDIVIDUAL AND SITUATIONAL INFLUENCES ON THE DEVELOPMENT OF SELF-EFFICACY: IMPLICATIONS FOR TRAINING EFFECTIVENESS. PERSONNEL PSYCHOLOGY , 46.

[25]. Minjeong Kang, Minjung Sung. (2017). How symmetrical employee communication leads to employee engagement and positive employee communication behaviors The mediation of employeeorganization relationships. Journal of Communication Management, 82 - 102.

[26]. Morrison, E. W. (2014). Employee Voice and Silence. The Annual Review of Organizational Psychology and Organizational Behavior, 173-197.

[27]. Morrison, Elizabeth W. (2011). Employee Voice Behavior: Integration and Directions for Future Research. Academy of Management Annals, 373-412.

[28]. Muijs, D. (2004). Doing Quantitative Research in Education with SPSS. London • Thousand Oaks • New Delhi: SAGE Publications.

[29]. Narayan, K. H. (2015). Intrinsic Motivation, Organizational Justice, and Creativity. Creativity Research Journal, 214-224.

[30]. Ni, L. (2007). Refined understanding of perspectives on employee-organization relationships. Journal of Communication Management, 53-70.

[31]. O'BRIEN , R. M. (2007). A Caution Regarding Rules of Thumb for Variance Inflation Factors. Springer, 674-690.

[32]. O’Brien, R. M. (2007). A Caution Regarding Rules of Thumb for Variance Inflation Factors. Quality \& Quantity, 41, 673-690. 
[33]. Odom, L. R., \& Henson, R. K. (2002, feb. 15). DATA SCREENING: ESSENTIAL TECHNIQUES. Paper presented at the annual meeting of the Southwest Educational Research Association.

[34]. Park, K. K.-N. (2014). Bottom-Up Building of an Innovative Organization: Motivating Employee Intrapreneurship and Scouting and Their Strategic Value. Management Communication Quarterly, 1-30.

[35]. Rhee, J.-N. K. (2011). Strategic Thinking about Employee Communication Behavior (ECB) in Public Relations: Testing the Models of Megaphoning and Scouting Effects in Korea. Journal of Public Relations Research, 243-268.

[36]. Richard D. Waters, D. S. (2013). Can public relations improve the workplace? Measuring the impact of stewardship on the employer-employee relationship . emeraldinsight, 613-629.

[37]. Robbins, J. S. (2016). Organizational Behavior. United States: Pearson Education.

[38]. Russell Cropanzano, M. S. (2005). Social Exchange Theory: An Interdisciplinary Review. Journal of Management, 874-900 .

[39]. Sahinidis , A. G., \& Bouris, J. (2006). Employee perceived training effectiveness relationship to employee attitudes. Journal of European Industrial Training, 63-76.

[40]. Santos, Â., \& Reynaldo, J. (1999). Cronbach's Alpha: A Tool for Assessing the Reliability of Scales. Journal of extension, 1-5.

[41]. Sirota, D., \& Klein, D. A. (2014). The Enthusiastic employee: how companies profit by giving workers what they want. New Jersey : person .

[42]. SUN, W., CHOU, C.-P., STACY, A. W., \& MA, H. (2007). SAS and SPSS macros to calculate standardized Cronbach's alpha using the upper bound of the phi coefficient for dichotomous items. Behavior Research Methods, 71-81.

[43]. Sunil Ramlall, P. (2004). A Review of Employee Motivation Theories and their Implications for Employee Retention within Organizations . The Journal of American Academy of Business, Cambridge , 52-63.

[44]. Tavakol, M., \& Dennick, R. (2011). Making sense of Cronbach's alpha. International journal of medical education, 53-55.

[45]. Terence R. Mitchell, B. C. (2011). How to keep your best employees: Developing an effective retention policy. Academy of Management Perspectives , 96108.

[46]. Tiffany Derville Gallicano, P. C. (2012). I Love What I Do, But... A Relationship Management Survey of Millennial Generation Public Relations Agency Employees. Journal of Public Relations Research, 222-242.

[47]. Trevor W. Robbins, B. J. (1996). Neurobehavioural mechanisms of reward and motivation. Current Opinion in Neurobiology , 228-236.

[48]. UCLA. (n.d.). What does Cronbach's alpha mean? SPSS FAQ. Retrieved from Institute for digital Research https://stats.idre.ucla.edu/spss/faq/what-doescronbachs-alpha-mean

[49]. Vidal, R. V. (2004). The Vision Conference Facilitating creative processes. IMM, Technical University of Denmark (p. 18). Denmark: Kluwer Academic Publishers-Plenum Publishers.

[50]. XIAOMENG ZHANG, K. M. (2010). As we indicated earlier, the degree of engagement in the creative process varies. If an individual pays little attention to a problem and chooses to minimally engage in its resolution,

solutionsmaynotbecreativeanduseful.Ontheother hand, creative solution. Academy of Management Journal , 107-128. 